\title{
The role of grit and parent-child communication in career adaptability
}

\author{
Doddy Hendro Wibowo, ${ }^{1 *}$ Krismi Diah Ambarwati, ${ }^{1}$ Pietro Crescenzo ${ }^{2}$ \\ ${ }^{1}$ Faculty of Psychology, Universitas Kristen Satya Wacana, Salatiga - Indonesia, ${ }^{2}$ Migranti senza Frontiere \\ Association, Salerno - Italy
}

\begin{abstract}
The transition period from school to the world of work is a critical time that affects determining one's career. This study aims to examine the role of grit and parent-child communication in students' career adaptability. Using a purposive sampling technique, the study involved 218 High School (SMA) students and 124 Vocational High School (SMK) students in Salatiga, Indonesia. The measurement instruments used in the research were the career adaptability scale, grit scale, and parent-child communication scale. The results show that the R-value was .595 and the adjusted $R$ squared $\left(\mathrm{R}^{2}\right)$ value was .354 . The significance value generated from the regression test was $.000(\mathrm{p}<.01)$. Based on the calculation results, it can be concluded that grit and communication between parents and children together play a significant role in career adaptability. The research implication is that students' grit and effective parent-child communication should be developed to improve career adaptability.
\end{abstract}

Keywords: grit; parent-child communication; career adaptability

\begin{abstract}
Abstrak: Periode transisi dari jenjang sekolah menuju dunia pekerjaan adalah periode kritis yang memengaruhi penentuan karir seseorang. Penelitian ini bertujuan untuk mengetahui peran grit dan komunikasi orang tua dengan anak terhadap adaptabilitas karir pada siswa. Dengan menggunakan teknik purposive sampling, penelitian ini melibatkan partisipan siswa di jenjang Sekolah Menengah Atas (SMA) sejumlah 218 siswa dan Sekolah Menengah Kejuruan (SMK) sejumlah 124 siswa di Salatiga, Indonesia. Alat ukur yang digunakan dalam penelitian ini adalah skala adaptabilitas karir, skala grit, dan skala komunikasi orang tua dengan anak. Hasil penelitian menunjukkan nilai R sebesar 0,595 dan nilai adjusted $R$ square $\left(\mathrm{R}^{2}\right)$ sebesar 0,354 . Nilai signifikansi yang dihasilkan dari uji regresi yaitu sebesar $0,000(p<0,05)$. Berdasarkan hasil penghitungan maka dapat disimpulkan bahwa grit dan komunikasi orang tua dengan anak secara bersama-sama berperan secara signifikan terhadap adaptabilitas karir.
\end{abstract}

Kata Kunci: grit; komunikasi orang tua dengan anak; adaptabilitas karir 


\section{Introduction}

The transition period from school to the world of work is critical in young people's developmental stage and affects the career determination process (Koen et al., 2012). During this time, adapting is an important characteristic that needs to be possessed when facing career transition problems (Yousefi et al., 2011). Middle school plays an important role, being the time when students start choosing majors according to their talents and interests and concerning college entry or work ambitions. On the other hand, students are also at the maturation stage of professional maturity and identity (Mardiyati \& Yuniawati, 2015). Commonly, career problems are doubt and indecisiveness among high school students. They tend to care less and follow their friend's career choices. As a result, they choose education majors randomly. They did not consider their talents and interests (Atmaja, 2014). The results of initial interviews in this research with several students also showed that they tended not to be ready to choose a major before going to college, were confused after graduating about where they would work, and could not determine which career to pursue. Therefore, students need to be equipped with affective resources when they are ready to become lifelong learners, have flexibility, quickly learn to use the latest technology, and maintain their performance (Savickas et al., 2009). They need to have soft skills known as career adaptability.

Savickas (1997) defines career adaptability as a form of readiness to cope with situations, participate, and do work tasks, including adapting to unpredictable conditions due to changes in the work environment. It is a resource that shapes people to more easily develop, form goals, explore, organize, and maximize their potential, so that career goal can be achieved (Savickas, 1997; Savickas \& Porfeli, 2012).

Savickas and Porfeli (2012) discuss four aspects of career adaptability: 1) Career attention, being the ability to consider and prepare for work, including paying attention to the future, feeling optimistic, having positive attitudes, planning, and having positive expectations about the career to be pursued; 2) Career control, which is the ability to make decisions and take action, including increasing self-regulation in order to be responsible for the future, having a positive attitude towards choosing an education major, and being assertive and independent in determining one's career; 3) Career curiosity, the strength to explore various situations and roles, including curiosity and productive exploration of potential careers, which allows adolescents to explore education and meaningful choices of major; and 4) Career confidence, which is a belief in problem solving skills, including the ability to find solutions to problems, self-confidence in overcoming difficulties when building a career, being diligent and confident, and being able to build relationships with other people.

Students who want to achieve their goals need to work hard to face challenges and maintain a strong effort and interest. Challenges include difficulties, setbacks, and even failures that can occur over time and also recur. Therefore, is needed when facing various disappointments or boredom so that people stay focused on their goals. The soft skill needed is known as grit, which refers to the persistence and passion for long-term goals and includes consistency of goals and interest and persistence of efforts (Duckworth et al., 2007). Persistence is characterized by the striving to achieve goals 
even over a long period of time, trying to conquer challenges and difficulties, being diligent, working hard, and ultimately being able to achieve one's desired goals. On the other hand, consistency of interest is characterized by having definite and clear goals, not being easily distracted and changing goals, and having a persistent desire (Duckworth et al., 2007).

Students who have grit are shown to have clear ideas, encouraging them to achieve high grades; to be always involved in activities that support their goals; to be focused; and to be able to consider various majors when deciding which career to pursue (S. Lee \& Sohn, 2017). They will also be able to achieve difficult tasks, and not give up easily even if this requires a great effort, due to the sense of optimism about the task (Lucas et al., 2015). Students with high grit will begin planning their goals from an early age, starting by choosing a major that suits their wants and interests. They will also strive to obtain high grades and be achievers in class (Jiang et al., 2019), showing a mindset that continues to develop while continually referring to their ideals (Polirstok, 2017). However, on the other hand, the grit variable seems to play a more minor role and become less productive when one is faced with jobs that are well organized, are easy to do, and which do not require high levels of creativity (Clark \& Clark, 2019; Credé et al., 2017).

In addition, other factors influence career adaptability, namely the support of parents and family (Lee, 2018; Sahin \& Kirdok, 2018; Tian \& Fan, 2014), and parenting patterns (Jung \& Ahn, 2018) which play a significant role in shaping career adaptability. Positive communication between parents and children about careers can show parents' involvement and warmth, and that there is support available when children experience pressure or difficulties in achieving their goals (Dietrich \& Salmela-Aro, 2013). Children who have a high level of happiness, a positive attitude, an effective career plan, and receive full social support from their parents and friends will be more adaptive in their career choice (Öztemel \& Ylldı-Akyol, 2019). Conversely, a lack of concern from those around them will make children feel pessimistic and do not care about their careers.

Previous studies show that one of the factors that influence career adaptability is the relationship between parents and children. Parents play a dominant role in providing early-career knowledge and helping with the efforts needed to achieve their children's goals. Besides, they also provide a sense of trust and build children's self-confidence to be capable and successful in achieving their goals (Amarnani et al., 2018). Parents who stimulate their children to be curious about career choices will increase their knowledge of the world of work and foster exploratory behavior. The career confidence aspect enables young people to solve problems when facing challenges in their choice of career, adapt to various changes and new situations (Hamtiaux et al., 2013), and have confidence in their chosen career. This confidence will be shown through diligent and persistent behavior in achieving goals (Hartung et al., 2008).

Based on the discussion above, this study aims to examine the role of grit and communication between parents and children in students' career adaptability. The hypothesis proposed is that together grit and communication between parents and children play a role in students' career adaptability. 


\section{Method}

The research participants were selected from private secondary schools in the city of Salatiga using the purposive sampling technique; they comprised 218 High School (SMA) and 124 Vocational High School (SMK) students, with an age range of 13 to 20 . The complete data are presented in Table 1.

The measurement instrument used in the study was adapted from the Career Adaptability Scale developed by Savickas. The aspects included were career attention, career control, career curiosity, and career confidence (Maggiori et al., 2017). The grit measuring tool was adapted from Duckworth's grit scale, comprising aspects of business persistence and consistency of interest (Duckworth \& Quinn, 2009). Finally, the parentchild communication scale was adapted from the Parent-Child Relationships Schema Scale, consisting of the following aspects: activities that parents must do for their children; activities that children must-do for parents; activities that parents and children do together; the feelings of the children and the parents; and activities that children and parents participate in (Dixson et al., 2014). The researcher performed the scale adaptation process, followed by expert judgment, and finally, the legibility test was conducted. A readability test was also held with several students at the high school level to ensure that they were easy to understand and provided input on whether the statement items had been translated correctly.

The Career Adaptability Scale consisted of 24 statement items with tiered answer choices, namely Strongly Agree (SS), Agree (S), Doubt (R), Disagree (TS), and Strongly Disagree (STS), with a maximum value of 5 and a minimum of 1 . Some examples of statements on the Career Adaptability Scale were: "I am thinking about what my future will be"; "I always think negatively about my future"; and "I was able to overcome obstacles in achieving my goals".

The Grit Scale comprised 12 statement items with the same tiered answer choices, Strongly Agree (SS), Agree (S), Doubt (R), Disagree (TS), and Strongly Disagree (STS), also with a maximum value of 5 and a minimum value of 1 . Some examples of statements on this scale were: "I will finish whatever I have started"; "I am not easily attracted to every new activity"; and "I'm a hard worker."

Table 1

Demographic Data of the Research Subjects

\begin{tabular}{lccc}
\hline Number of students & $\begin{array}{c}\text { Vocational High School } \\
\text { (SMK) }\end{array}$ & High School (SMA) & Total \\
\hline Male & 53 & 117 & 170 \\
Female & 71 & 101 & 172 \\
\hline Total & 124 & 218 & 342 \\
\hline
\end{tabular}

Table 2

Reliability and Validity of Measurement Instruments

\begin{tabular}{lc}
\hline Scale & Reliability (Cronbach alpha) \\
\hline Career Adaptability & .840 \\
Grit & .721 \\
Parent-Child Communication & .957 \\
\hline
\end{tabular}


The Parent-Child Communication Scale consisted of 40 statement items, again with the same tiered answer choices of Strongly Agree (SS), Agree (S), Doubt (R), Disagree (TS), and Strongly Disagree (STS). Some examples of statements on this scale were: "Parents and I have time to play together"; "My parents and I help each other"; and "I listen to my parents and do what they say".

Based on the reliability calculation, the measurement instrument's level of consistency was obtained and presented in Table 2.

\section{Results}

Based on the research results, the following descriptive data shown in Table 3. Table 3 shows that out of the 342 samples (N) used in the study, the average (mean) value of the career adaptability variable was 94.80 ; the average (mean) value of the grit variable was 40.23 , and the average (mean) value of the parent-child communication variable was 161.95 . Table 3 also shows that most of the participants had career adaptability scores that were in the medium category (71.9\%), with grit scores also mostly in the medium category (66.7\%), and parent-child communication scores similarly mostly in the medium category (71.1\%).

The results of the assumption test show that the data were normally distributed. The significance value of the Kolmogorov-Smirnov test shows a level of .200 ( $p>$.05). The linearity test showed that the Career Adaptability Scale and Grit had a significance value of $.000(\mathrm{p}<.05)$. The Career Adaptability Scale and Parent-Child Communication also had a significance value of $.000(\mathrm{p}<.05)$, which means that both sets of data can be said to be linear. The multicollinearity test showed the value of the Variance Inflation Factor (VIF) was 1.073 (VIF < 10), with a tolerance value of 0.932 for the grit and parent and child communication variables, so it can be concluded that there is no multicollinearity disorder in the pairs of independent variables.

Table 3

Descriptive Data of Research Results

\begin{tabular}{lccc}
\hline & Career Adaptability & Grit & Parent-Child Communication \\
\hline $\mathrm{N}$ & 342 & 342 & 342 \\
Empirical Mean & 94.80 & 40.23 & 161.95 \\
$\mathrm{SD}$ & 9.155 & 5.254 & 21.067 \\
Min. & 64 & 26 & 66 \\
Max. & 119 & 56 & 199 \\
Low Category & $53(15.5 \%)$ & $47(13.7 \%)$ & $43(12.6 \%)$ \\
Medium Category & $246(71.9 \%)$ & $228(66.7 \%)$ & $243(71.1 \%)$ \\
High Category & $43(12.6 \%)$ & $67(19.6 \%)$ & $56(16.4 \%)$ \\
\hline
\end{tabular}

Table 4

Multiple Regression Test Results: R-Value

\begin{tabular}{cc|c|c|c}
\hline Model & $\mathrm{R}$ & R Squared & Adjusted R Squared & Std. Error of the Estimate \\
\hline 1 & $.595^{\mathrm{a}}$ & .354 & .350 & 7.379 \\
\hline & & & &
\end{tabular}


The R-value in Table 4 is the regression coefficient of .595, while the adjusted R squared $\left(R^{2}\right)$ value which has a coefficient of determination of 354 . The adjusted $\mathrm{R}^{2}$ value shows the role or contribution of the two independent variables, namely grit and communication, between parents and children with regard to the dependent variable, namely career adaptability, in a regression test that involved more than two variables. The results of the multiple regression tests between the independent and dependent variables have a meaning, namely that grit and communication between parents and children simultaneously contribute to career adaptability by $35.4 \%$, while other factors determine the remaining $64.6 \%$.

The significance value in Table 5 generated from the regression test is equal to $.000(\mathrm{p}<.05)$.
It shows that the study's regression model can predict the dependent variable, namely career adaptability. Based on the results obtained, it can be concluded that together, grit and communication between parents and children play a significant role in career adaptability.

Based on Table 6, it can be seen that the value of the beta coefficient (standardized coefficients) on the grit variable is 0.396 and that the significance is $.000(\mathrm{p}<.05)$, meaning that the grit variable has a significant effect on the career adaptability variable. Besides, the value of the beta coefficient (standardized coefficients) on the communication between parents and children variable was 0.352 , with significance of .000 $(\mathrm{p}<.05)$, so this variable also has a significant effect on the career adaptability variable.

Table 5

Multiple Regression Test Results: Significance of F Value

\begin{tabular}{lccccc}
\hline Model & Sum of Squares & Df & Mean Square & F. & Sig. \\
\hline Regression & 10118.227 & 2 & 5059.113 & 92.901 & $.000^{\mathrm{b}}$ \\
Residual & 18460.852 & 339 & 54.457 & & \\
Total & 28579.079 & 341 & & & \\
\hline
\end{tabular}

Table 6

Multiple Regression Test Results: Beta Coefficient Value

\begin{tabular}{|c|c|c|c|c|c|}
\hline \multirow{3}{*}{ Model } & \multicolumn{2}{|c|}{$\begin{array}{l}\text { Unstandardized } \\
\text { Coefficients }\end{array}$} & \multirow{3}{*}{$\begin{array}{c}\text { Standardized } \\
\text { Coefficients } \\
\text { Beta }\end{array}$} & \multirow{3}{*}{$\mathrm{T}$} & \multirow{3}{*}{ Sig. } \\
\hline & & Std. & & & \\
\hline & B & Error & & & \\
\hline \multirow{4}{*}{$\begin{array}{ll}1 & \text { (Constant) } \\
& \text { Grit } \\
& \text { Parent-Child } \\
& \text { Communication }\end{array}$} & 42.234 & 3.881 & & 10.882 & .000 \\
\hline & 690 & .079 & .396 & 8.762 & .000 \\
\hline & .153 & .020 & .352 & 7.789 & .000 \\
\hline & & & & & \\
\hline
\end{tabular}




\section{Discussion}

Based on the results of the analysis using the multiple regression tests, it can be seen that the research hypothesis that together grit and communication between parents and children play a role in students' career adaptability can be accepted. This is based on the R coefficient of the regression test results of .595, and the significance value of the F-test of .000, which indicate that grit and communication between parents and children together play a significant role in career adaptability. The results of this study support previous research, which found that students with high grit undertake more career planning according to their goals and interests (Jiang et al., 2019). Research by Amarnani et al. (2018) found that parents played a dominant role in providing early-career knowledge, building children's selfconfidence, and supporting children's efforts to achieve their goals.

The psychological dynamics of students who have high grit and good communication between parents and children will improve career adaptability. This can be explained as follows. Career adaptability consists of four aspects; the first, career attention, is how students prepare for their desired goals. This is achieved by showing an interest in a certain field of work, followed by a stronger sense of interest. Students direct their thoughts and behavior towards exploring and seeking information and opportunities to pursue their goals. Next, in the career control stage, students will determine their goals, determine their responsibilities, and be more self-regulating after doing this. In the next stage, students will explore various aspects of their aspirations; for example, future job opportunities, skills that need to be prepared and learned, and choice of major when entering college. The final aspect is career confidence; after students have finalized their choice, all their efforts and time will be directed toward achieving their goals. They will then have the belief that with their potential for intelligence, opportunities, and interest, they will be able to secure their desired job. The difficulties and problems they face will not become obstacles, but they will continue to make an effort and not give up when building a career and developing extensive social relationships to support their dreams until finally achieving their goals. Grit can also be a differentiating factor in the performance of two people who have the same abilities. Those with high grit will be able to use their abilities more productively, will be less easily distracted by short-term goals, and less likely to become discouraged when experiencing failure (Credé et al., 2017). In this case, students who have high grit will survive and focus on the career they want to pursue, so achieving success.

Parents play a significant role in their children's career development by providing knowledge and understanding for children; giving rewards in each career process; and providing support and direct involvement in their children's career process (Guan et al., 2018). Parents also play an important role in influencing their children's interests and ideas, supporting all the efforts made to achieve their goals, and providing verbal support in the form of praise or direction related to their school achievement (Ferry et al., 2000). The process of open communication between parents and children is an exploration activity, involving planning the future, and influencing career selection process. Parents play a role in encouraging their children, supporting their decisions through discussions in 
which they express their support and interest in the children's activities. In addition, parents are also the main source of children's career knowledge by providing informative material about work, participating in various career development workshops, or information about aptitude and interest tests (Paloş \& Drobot, 2010).

Parents play a major role for children in their career decisions, especially during the transition from school to college. Although peers also sometimes influence children's career choices, the role of parents is still more dominant (Kumar, 2016). Parents play an important role in identifying and guiding the process of developing children's talents. The interaction between parents and children is an intermediary process that helps children understand society's demands, the environment, and the business world, which need to be emphasized in developing children's careers (Zahedani et al., 2016). The study results show that parental support is also a form of trust and respect for children's choices. It will help children imagine their career path and achieve their goals so that they can have the confidence to overcome these when faced with difficulties. Therefore, in the career counseling process, parental involvement is the main contributor to career success (Ginevra et al., 2015).

The application of this research results involves the importance of developing persistence and consistency in students, supported by effective parent-child communication, which it is hoped will improve their career adaptability. The results of the calculations in Table 3 show that most of the participants had career adaptability values that were in the medium category (71.9\%), with grit values also mostly in the medium category (66.7\%), and similarly communication between parents and children values mostly in the medium category (71.1\%). Therefore, improvement in the adaptability of career, grit, and communication between parents and children must be no longer delayed. This can be achieved by providing a learning environment that supports and involves students in various school activities (Tang et al., 2019). Besides, parents and children also need to establish communication to understand appropriate techniques and strategies to encourage children's exploration and increase children's confidence that their parents support their career ambition (Ginevra et al., 2015). In the career counseling process, it is important to involve parents to create interactive dialogue and understand what both the parents and the children want. Besides, communication between parents and children is believed to be good if there is acceptance, mutual support, and openness. This can be done through collective recreation, such as celebrating special days by giving and receiving, creating trust in children and children in their parents, and encouraging them to achieve in their favorite fields (Isadora et al., 2012).

\section{Conclusion}

It is concluded that the variables of grit and communication between parents and children together play a significant role in career adaptability. In particular, grit and communication between parents and children have a significant effect on career adaptability. In particular, the value of students' career adaptability is in the medium category (71.9\%), as is their grit score (66.7\%), and that of communication between parents and children (71.1\%). 
Acknowledgments

The authors would like to express their sincere gratitude to the Research, Development, and Community Service Bureau (BP3M) of Universitas Kristen Satya Wacana (UKSW)
Salatiga for funding this research by Research and Community Service Grants for the year 2019/2020.]

\section{References}

Amarnani, R. K., Garcia, P. R. J. M., Restubog, S. L. D., Bordia, P., \& Bordia, S. (2018). Do you think I'm worth it? The self-verifying role of parental engagement in career adaptability and career persistence among STEM students. Journal of Career Assessment, 26(1), 77-94. https://doi.org/10.1177/1069072716679925

Atmaja, T. T. (2014). Upaya meningkatkan perencanaan karir siswa melalui Bimbingan Karir dengan penggunaan media modul. Psikopedagogia: Jurnal Bimbingan dan Konseling, 3(2), 58-68. https://doi.org/10.12928/psikopedagogia.v3i2.4466

Clark, R. S., \& Clark, V. L. P. (2019). Grit within the context of career success: A mixed methods study. International Journal of Applied Positive Psychology, 4, 91-111.

Credé, M., Tynan, M. C., \& Harms, P. D. (2017). Much ado about grit: A meta-analytic synthesis of the grit literature. Journal of Personality and Social Psychology, 113(3), 492-511. https://doi.org/10.1037/pspp0000102

Dietrich, J., \& Salmela-Aro, K. (2013). Parental involvement and adolescents' career goal pursuit during the post-school transition. Journal of Adolescence, 36(1), 121-128. https://doi.org/10.1016/j.adolescence.2012.10.009

Dixson, M., Bermes, E., \& Fair, S. (2014). An instrument to investigate expectations about and experiences of the parent-child relationship: The parent-child relationship schema scale. Social Sciences, 3(1), 84-114. https://doi.org/10.3390/socsci3010084

Duckworth, Angela L., Peterson, C., Matthews, M. D., \& Kelly, D. R. (2007). Grit: Perseverance and passion for long-term goals. Journal of Personality and Social Psychology, 92(6), 1087-1101. https://doi.org/10.1037/0022-3514.92.6.1087

Duckworth, Angela Lee, \& Quinn, P. D. (2009). Development and validation of the short grit scale (GritS). Journal of Personality Assessment, 91(2), 166-174. https://doi.org/10.1080/00223890802634290

Ferry, T. R., Fouad, N. A., \& Smith, P. L. (2000). The role of family context in a social cognitive model for career-related choice behavior: A math and science perspective. Journal of Vocational Behavior, 57(3), 348-364. https://doi.org/10.1006/jvbe.1999.1743

Ginevra, M. C., Nota, L., \& Ferrari, L. (2015). Parental support in adolescents' career development: Parents' and children's perceptions. The Career Development Quarterly, 63(1), 2-15. https://doi.org/10.1002/j.2161-0045.2015.00091.x

Guan, Y., Wang, Z., Gong, Q., Cai, Z., Xu, S. L., Xiang, Q., Wang, Y., Chen, S. X., Hu, H., \& Tian, L. (2018). Parents' career values, adaptability, career-specific parenting behaviors, and undergraduates'

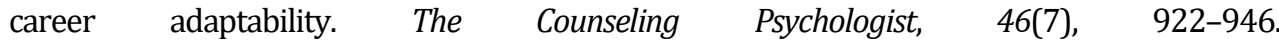
https://doi.org/10.1177/0011000018808215 
Hartung, P. J., Porfeli, E. J., \& Vondracek, F. W. (2008). Career adaptability in childhood. The Career Development Quarterly, 57(1), 63-74. https://doi.org/10.1002/j.2161-0045.2008.tb00166.x

Isadora, S., Pratiwi, S., \& Tjondronegoro, P. (2012). Perbedaan motif afiliasi pada remaja pengguna Facebook ditinjau dari jenis kelamin. Intuisi: Jurnal Psikologi Ilmiah, 4(3), 147-151. https://doi.org/10.15294/intuisi.v4i3.13348

Jiang, W., Xiao, Z., Liu, Y., Guo, K., Jiang, J., \& Du, X. (2019). Reciprocal relations between grit and academic achievement: A longitudinal study. Learning and Individual Differences, 71(19), 13-22. https://doi.org/10.1016/j.lindif.2019.02.004

Jung, E., \& Ahn, D. (2018). Relationship among parental psychological control, autonomy support, and career adaptability of university students: The mediating role of career decision-making autonomy. The IIER International Conference, February, 21-23.

Koen, J., Klehe, U., \& Van Vianen, A. E. M. (2012). Training career adaptability to facilitate a successful school-to-work transition. Journal of Vocational Behavior, 81(3), 395-408. https://doi.org/10.1016/j.jvb.2012.10.003

Kumar, S. (2016). Parental influence on career choice traditionalism among college students in selected cities in Ethiopia. International Journal of Psychology and Educational Studies, 3(3), 23-30. https://doi.org/10.17220/ijpes.2016.03.003

Lee, I. H. (2018). The link between socioeconomic status and career adaptability among Korean adolescents: The mediating role of parental career-related support. Career and Technical Education Research, 43(1), 57-75. https://doi.org/10.5328/cter43.1.57

Lee, S., \& Sohn, Y. W. (2017). Effects of grit on academic achievement and career-related attitudes of college students in Korea. Social Behavior and Personality: An International Journal, 45(10), 1629-1642. https://doi.org/10.2224/sbp.6400

Lucas, G. M., Gratch, J., Cheng, L., \& Marsella, S. (2015). When the going gets tough: Grit predicts costly perseverance. Journal of Research in Personality, 59, 15-22. https://doi.org/10.1016/j.jrp.2015.08.004

Maggiori, C., Rossier, J., \& Savickas, M. L. (2017). Career adapt-abilities scale-short form (CAAS-SF). Journal of Career Assessment, 25(2), 312-325. https://doi.org/10.1177/1069072714565856

Mardiyati, B. D., \& Yuniawati, R. (2015). Perbedaaan adaptabilitas karir ditinjau dari jenis sekolah (SMA dan SMK). Empathy: Jurnal Fakultas Psikologi, 3(1), 31-41.

Öztemel, K., \& Ylldı-Akyol, E. (2019). The predictive role of happiness, social support, and future time orientation in career adaptability. Journal of Career Development, April, 1-14. https://doi.org/10.1177/0894845319840437

Paloș, R., \& Drobot, L. (2010). The impact of family influence on the career choice of adolescents. Procedia - Social and Behavioral Sciences, 2(2), 3407-3411. https://doi.org/10.1016/j.sbspro.2010.03.524

Polirstok, S. (2017). Strategies to improve academic achievement in secondary school students: Perspectives on grit and mindset. SAGE Open, 7(4), 1-9. https://doi.org/10.1177/2158244017745111

Sahin, I., \& Kirdok, O. (2018). Investigation of relationship between high school students' career adaptability, subjective well-being and perceived social support. International Education Studies, 11(8), 127-135. https://doi.org/10.5539/ies.v11n8p127 
Savickas, M. L. (1997). Career adaptability: An integrative construct for life-span, life-space theory. The Career Development Quarterly, 45(3), 247-259. https://doi.org/10.1002/j.21610045.1997.tb00469.x

Savickas, M. L., Nota, L., Rossier, J., Dauwalder, J., Duarte, M. E., Guichard, J., Soresi, S., Van Esbroeck, R., \& van Vianen, A. E. M. (2009). Life designing: A paradigm for career construction in the 21st century. Journal of Vocational Behavior, 75(3), 239-250. https://doi.org/10.1016/j.jvb.2009.04.004

Savickas, M. L., \& Porfeli, E. J. (2012). Career adapt-abilities scale: Construction, reliability, and measurement equivalence across 13 countries. Journal of Vocational Behavior, 80(3), 661-673. https://doi.org/10.1016/j.jvb.2012.01.011

Tang, X., Wang, M., Guo, J., \& Salmela-Aro, K. (2019). Building grit: The longitudinal pathways between mindset, commitment, grit, and academic outcomes. Journal of Youth and Adolescence, 48(5), 850-863. https://doi.org/10.1007/s10964-019-00998-0

Tian, Y., \& Fan, X. (2014). Adversity quotients, environmental variables and career adaptability in student nurses. Journal of Vocational Behavior, 85(3), 251-257. https://doi.org/10.1016/j.jvb.2014.07.006

Yousefi, Z., Abedi, M., Baghban, I., Eatemadi, O., \& Abedi, A. (2011). Personal and situational variables, and career concerns: Predicting career adaptability in young adults. The Spanish Journal of Psychology, 14(1), 263-271. https://doi.org/10.5209/rev_SJOP.2011.v14.n1.23

Zahed Zahedani, Z., Rezaee, R., Yazdani, Z., Bagheri, S., \& Nabeiei, P. (2016). The influence of parenting style on academic achievement and career path. Journal of Advances in Medical Education \& Professionalism, 4(3), 130-134. 
This page has been intentionally left blank. 